\title{
Gene expression of Hanwoo satellite cell differentiation in longissimus dorsi and semimembranosus
}

\author{
Sara de las Heras-Saldana ${ }^{1 \dagger}$, Ki Yong Chung ${ }^{2 \dagger}$, Seung Hwan Lee ${ }^{3^{*}}$ and Cedric Gondro ${ }^{4^{*}}$ (D)
}

\begin{abstract}
Background: Korean Hanwoo cattle are known for their high meat quality, especially their high intramuscular fat compared to most other cattle breeds. Different muscles have very different meat quality traits and a study of the myogenic process in satellite cells can help us better understand the genes and pathways that regulate this process and how muscles differentiate.

Results: Cell cultures of Longissimus dorsi muscle differentiated from myoblast into multinucleated myotubes faster than semimembranosus. Time-series RNA-seq identified a total of 13 differentially expressed genes between the two muscles during their development. These genes seem to be involved in determining muscle lineage development and appear to modulate the expression of myogenic regulatory factors (mainly MYOD and MYF5) during differentiation of satellite cells into multinucleate myotubes. Gene ontology enriched terms were consistent with the morphological changes observed in the histology. Most of the over-represented terms and genes expressed during myoblast differentiation were similar regardless of muscle type which indicates a highly conserved myogenic process albeit the rates of differentiation being different. There were more differences in the enriched $\mathrm{GO}$ terms during the end of proliferation compared to myoblast differentiation.

Conclusions: The use of satellite cells from newborn Hanwoo calves appears to be a good model to study embryonic myogenesis in muscle. Our findings provide evidence that the differential expression of HOXB2, HOXB4, HOXB9, HOXC8, FOXD1, IGFN1, ZIC2, ZIC4, HOXA11, HOXC11, PITX1, SIM2 and TBX4 genes could be involved in the differentiation of Longissimus dorsi and Semimembranosus muscles. These genes seem to modulate the muscle fate of the satellite cells during myogenesis through a differential expression profile that also controls the expression of some myogenic regulatory factors (MYOD and MYF5). The number of differentially expressed genes across time was unsurprisingly large. In relation to the baseline day 0, there were 631, 155, 175, 519 and 586 DE genes in LD, while in SM we found 204, 0, 615, 761 and 1154 DE genes at days 1, 2, 4, 7 and 14 respectively.
\end{abstract}

Keywords: Hanwoo, Satellite cell, Muscle differentiation, Myogenesis, RNA-seq

\section{Background}

The Korean Hanwoo cattle is known for its meat quality and high marbling ability (intramuscular fat) [1]. Meat quality (e.g. juiciness, tenderness, flavor) is mainly determined by the structure of the meat and its fatty acid

\footnotetext{
*Correspondence: slee46@cnu.ac.kr; gondroce@msu.edu

†'Sara de las Heras-saldana and Ki Yong Chung contributed equally to this work.

${ }^{3}$ Division of Animal and Dairy Science, Chungnam National University, Deajeon, South Korea

${ }^{4}$ Department of Animal Science, Michigan State University, 474 S Shaw Lane, East Lansing, MI 48824, USA

Full list of author information is available at the end of the article
}

composition, both of which vary widely across muscle groups [1-3].

Transcriptional analysis has been very useful to characterize gene expression differences in muscles from different breeds, with divergent phenotypes and across muscle groups [4]. It has also helped us understand the genetic mechanisms that underpin muscle development (myogenesis) [5] and how muscle developmental differences observed at the proteomic [6] and transcriptomic levels $[7,8]$ can affect production traits. Myogenesis is mainly controlled by the Myogenic Regulatory Factors (MRFs) that modulate myoblast proliferation, migration

(c) The Author(s). 2019 Open Access This article is distributed under the terms of the Creative Commons Attribution 4.0 International License (http://creativecommons.org/licenses/by/4.0/), which permits unrestricted use, distribution, and 
and fusion [9]. There are four MRFs (MYF5, MYOD, MRF4/MYF6, and MYOG), however there are also several other genes that contribute to the regulation of growth and differentiation [10] and there are still many unknowns surrounding the exact molecular mechanisms involved in muscle differentiation - particularly which genes change expression and when do these changes occur - that ultimately lead to the morphological and phenotypic differences observed across the different types of muscle.

Satellite cells are myogenic stem cells with the potential to self-renew and produce differentiated progeny; for this reason, these cells play an essential role in postnatal growth, muscle regeneration and hypertrophy. Myogenesis of satellite cells is a good model to study changes in gene expression over time and how they relate to muscle proliferation and differentiation $[7,8,11,12]$. The combination of RNA sequencing with histological techniques allows for a deeper understanding of the mechanisms mediating differentiation of satellite cells into different muscle types revealing their gene expression profile and regulatory mechanisms at specific differentiation stages. A better understanding of these mechanisms is important for developmental biology and can assist in the development of therapeutic protocols in muscle.

In this study, muscle biopsies were performed on three Hanwoo calves to extract muscle satellite cells from Longissimus dorsi (LD) and Semimembranosus (SM). Cells from these two muscles were cultured and allowed to differentiate into myotubes. This process was studied using RNA-seq and morphological measurements across six time points. The main objective of this study was to describe the expression profile of genes during early muscle differentiation in Hanwoo and to find differentially expressed genes between LD and SM muscles that may be involved in modulating muscle fate. We found that the gene expression profile over time is similar in both muscles which indicates a highly conserved myogenic process. However, our results indicate that the two muscles differentiate at different rates and that 13 genes seem to be involved in determining the fate of the satellite cells into one muscle type or another. Identification of the biological triggers in the early stages of muscle development can be of value to understand the different characteristics of muscles in adult cattle.

\section{Results}

\section{Morphological analysis}

The in vitro bovine muscle satellite cells (MSC) proliferated until they reached $60-70 \%$ confluence after four or 5 days of culture. The MSC were then treated with the differentiation medium and this timepoint was taken as day 0 (Fig. 1). Differentiation of bovine myoblasts began between 2 and 4 days later. LD formed multinucleated myotubes with significantly higher differentiation indexes compared to SM at days 3, 4 and 7 (Fig. 2) which suggests a faster differentiation process in LD myoblasts. This faster differentiation in LD also hints at a faster proliferation rate in comparison to SM, however it was not measured in this study. On day 7 , the myotubes of both muscles went through significant morphological changes by fusing to form mature multinucleated myotubes. There was also a significant reduction in the area occupied by the myotubes on day 7 in comparison to day 4 (Fig. 2). The differentiation indexes were calculated just for days 3,4 and 7 since no myotubes were detected on day 2 (Fig. 2).

\section{Sequencing and alignment to the $B$. taurus genome}

To characterize the gene expression profile during muscle differentiation, mRNA libraries were constructed at different stages of differentiation for LD and SM muscles. On average $80 \%$ of the paired reads mapped the $B$. taurus reference genome UMD3.1, from a mean value of $35,727,746$ total reads per sample (Table 1 and additional details of the processed reads in Additional file 1). The principal components analysis of the gene expression showed that the differentiation stage was the primary source of variation and accounted for $81 \%$ of the variation; the differences in expression between the two muscle types explained a relatively small proportion of the variance (Additional file 2).

\section{Gene expression analysis}

The stages of MSC differentiation observed in the histology aligned well with the qPCR time course expression of the Myogenic Regulatory Factors (MRF), PAX3 (paired box 3) and IGF1 (Insulin-like growth factor 1) in both muscles (Fig. 3). In LD, the expression of MYF5 Myogenic Factor 5 (Fig. 3) rapidly increased on day 2, with a subsequent reduction in mRNA abundance from day 4 until day 14 . This would be expected during the differentiation stage in which the myotubes were more abundant (Fig. 1). The expression in SM was relatively constant.

The expression of MYOD (myogenic differentiation 1) increased steeply after day 1 in LD. Expression levels were lower in SM and increases in expression were more gradual (Fig. 3). The increase of MYF6 (Myogenic Factor 6) mRNA is an indication of late differentiation which was observed from day 4 until day 14 ; here also a higher level of expression was observed in LD. MYOG (Myogenin) has a role in late differentiation [9] with the qPCR showing an increase in expression in both muscles from day 2 to day 14, and again a higher expression in LD. The higher expression of MYOD, MYF6 and MYOG in LD during the stage of late differentiation coincides with the faster differentiation observed in this muscle 


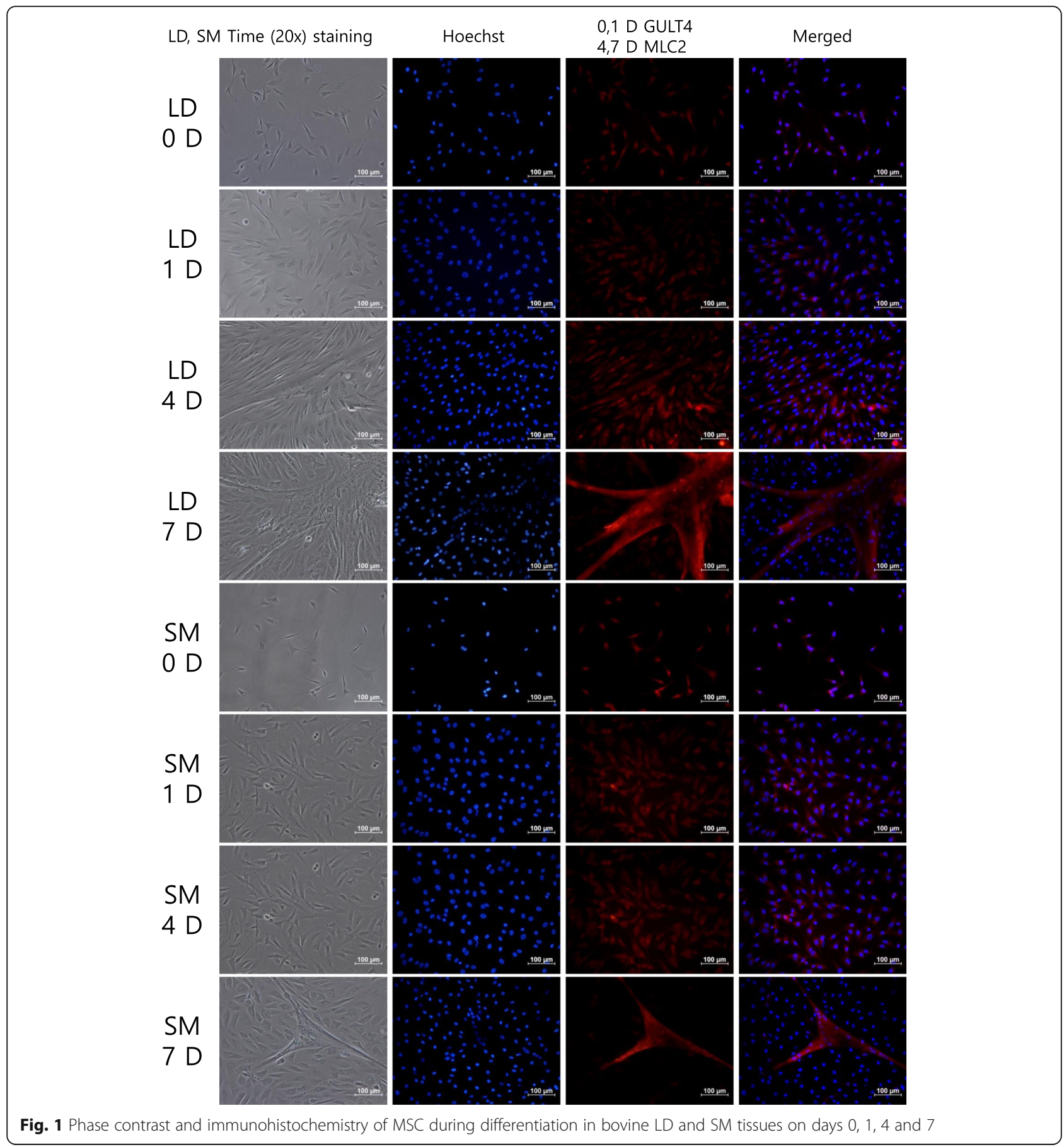

compared to SM (Fig. 2). The expression of $P A X 3$, which is high during proliferation of satellite cells, was consistently low during the differentiation stages in LD, however, there was an increase in its expression on day 14 in SM. The myogenic marker IGF1 showed an increased expression from day 4 until day 14 (Fig. 3).

The number of differentially expressed genes across time was unsurprisingly large (Fig. 4). In relation to the baseline day 0 , there were $631,155,175,519$ and 586
DE genes in LD, while in SM we found 204, 0, 615, 761 and $1154 \mathrm{DE}$ genes at days $1,2,4,7$ and 14 respectively (the complete list of DE genes is provided in Additional file 3).

Across all time points there were 13 genes differentially expressed between LD and SM (Additional file 3). The expression of the homeobox genes B2 (HOXB2), B4 (HOXB), B9 (HOXB9) and C8 (HOXC8), alongside forkhead box D1 (FOXD1), immunoglobulin-like and fibronectin type III domain containing 1 (IGFN), zinc finger 


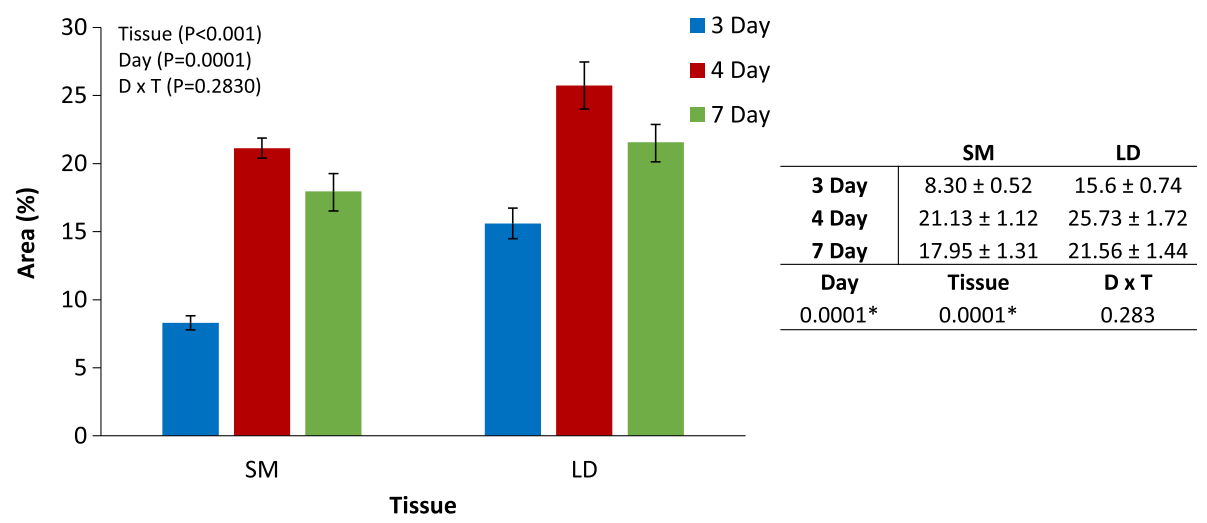

Fig. 2 Differentiation indexes (area occupied by myotubes) on days 3, 4 and 7 in SM and LD

members $2(Z I C 2)$ and 4 (ZIC4) were more abundant in LD, while the homeobox genes A11 (HOXA11) and C11 (HOXC11) plus paired-like homeodomain transcription factor 1 (PITX1), single-minded family bHLH transcription factor 2 (SIM2) and T-box 4 (TBX4) were more expressed in SM (Fig. 5 and Additional file 4). The consistent pattern of expression of these genes suggest that they could be involved in muscle fate differentiation into trunk or limb in cattle. Eight of these DE genes were randomly chosen for qPCR validation (Table 2). Significant differences in the relative expression levels were observed between muscles $(p<0.0001)$ confirming the results from the RNA-seq analysis.

\section{Functional analysis of differentially expressed genes}

The DE genes resulting from the time course analysis were used for a Gene Ontology (GO) and pathway enrichment analysis. Enriched GO terms (Table 3) for Cellular components included extracellular space,

Table 1 Summary of RNA-seq reads

\begin{tabular}{lllll}
\hline Muscle & Day & Total reads & Clean reads & Mapped reads \\
\hline LD & 0 & $64,653,898.67$ & $32,326,949.33$ & $82 \%$ \\
& 1 & $84,792,260$ & $42,396,130$ & $80 \%$ \\
& 2 & $83,802,156.67$ & $41,901,078.33$ & $80 \%$ \\
& 4 & $77,402,347.33$ & $33,542,207.33$ & $80 \%$ \\
& 7 & $59,158,033.33$ & $29,579,016.67$ & $80 \%$ \\
& 14 & $59,413,041.33$ & $29,706,520.67$ & $80 \%$ \\
& 0 & $68,553,754.67$ & $34,276,877.33$ & $83 \%$ \\
& 1 & $80,691,319.33$ & $40,657,234$ & $80 \%$ \\
& 2 & $83,065,964.67$ & $41,532,982.33$ & $81 \%$ \\
& 4 & $79,723,010$ & $39,861,505$ & $82 \%$ \\
& 7 & $62,983,208.67$ & $31,491,604.33$ & $81 \%$ \\
& 14 & $62,921,703.33$ & $31,460,851.67$ & $81 \%$ \\
\hline
\end{tabular}

The values presented are the average of the three biological replicates for each muscle and time point contractile fiber, myofibril, sarcomere, actin cytoskeleton and cytoskeletal part. For Biological processes, some of the enriched terms were cell cycle, cell proliferation, cytoskeleton organization and muscle structure development. Calcium ion binding, receptor activity and cytoskeletal protein binding were enriched terms in the Molecular functions domain. The full list of enriched ontology terms is presented in the supplementary material (Additional file 5).

At the beginning of the differentiation (day 1) most genes involved in any enriched GO term were down regulated in both muscles, which is consistent with the morphological changes observed in the histology. However, due to the structural changes observed when myoblasts differentiated into myotubes (days 7 and 14 in Fig. 1), more genes, especially those involved in cellular component terms like microtubule and sarcomere were up regulated (days 7 and 14, Table 3). The down regulation of genes involved in cell cycle, G2/M transition of mitotic cell cycle and cell proliferation in differentially expressed genes from days 7 and 14 corresponds to the shift from proliferation to differentiation that was observed in the cultures (Fig. 1). The proportion of DE genes changed mainly due to the advancement of differentiation. To get a better understanding of the shift from proliferation to differentiation, we plotted the $\log _{2}$-fold change of the genes involved in the term G2/M transition of mitotic cell cycle (Fig. 6). These genes were slightly upregulated at day 1 with a subsequent drop in abundance until day 4 and then low expression levels were maintained until day 14 in both muscles.

The main enriched pathways related with muscle differentiation were: complement and coagulation cascades, cardiac muscle contraction, calcium signaling pathway, cell cycle and DNA replication. The enriched pathways from the differentially expressed genes are reported for each muscle and time point in the supplementary material (Additional file 6). 


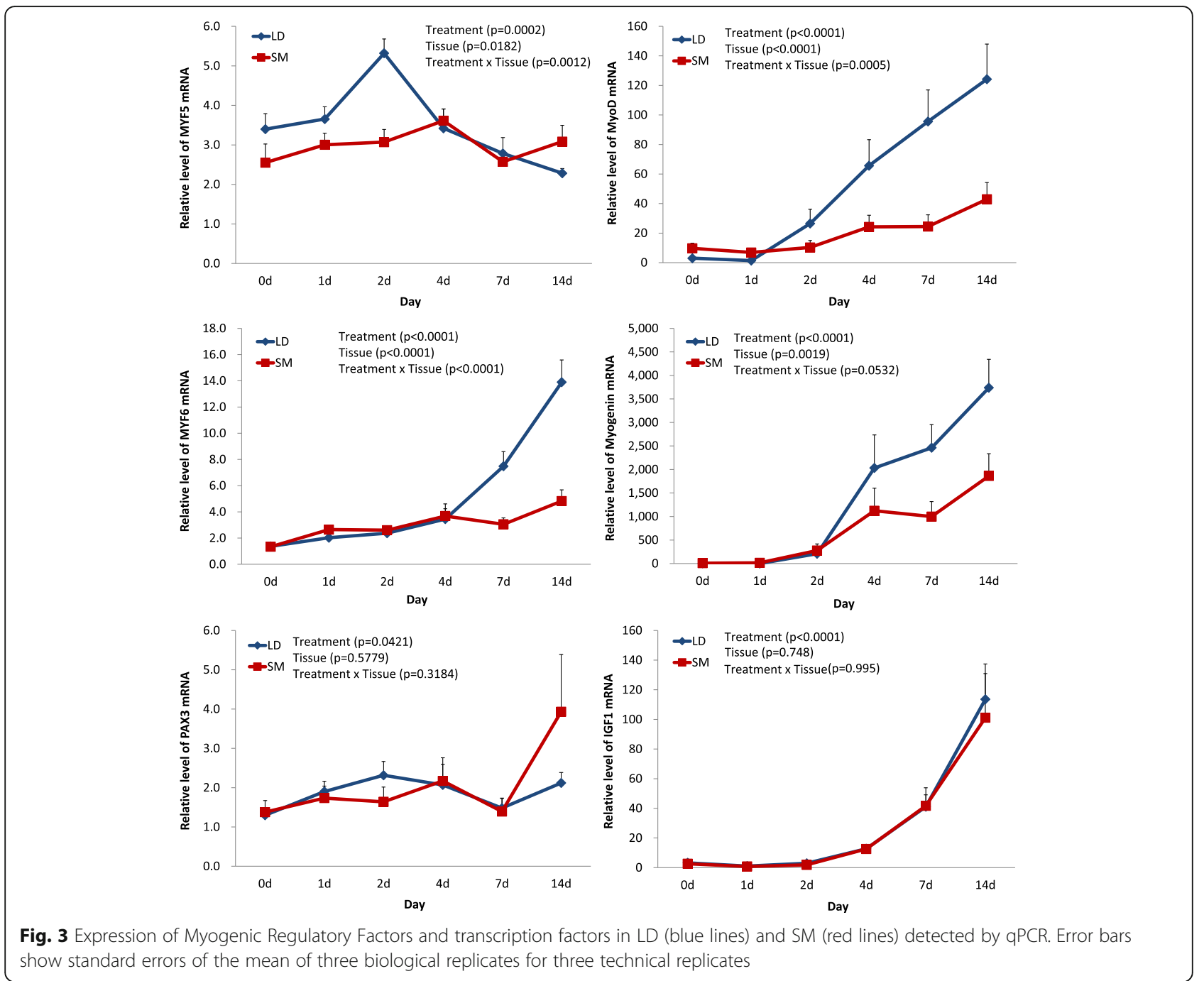

show standard errors of the mean of three biological replicates for three technical replicates

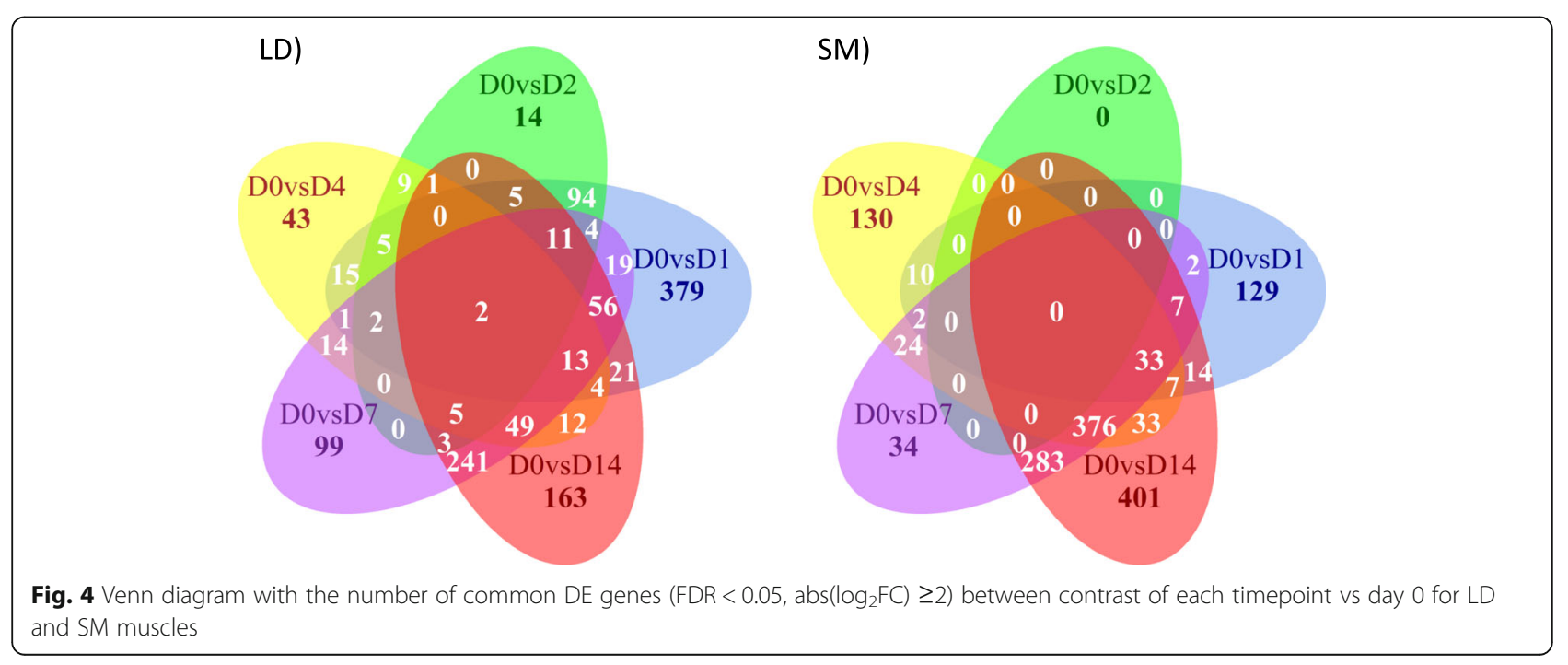




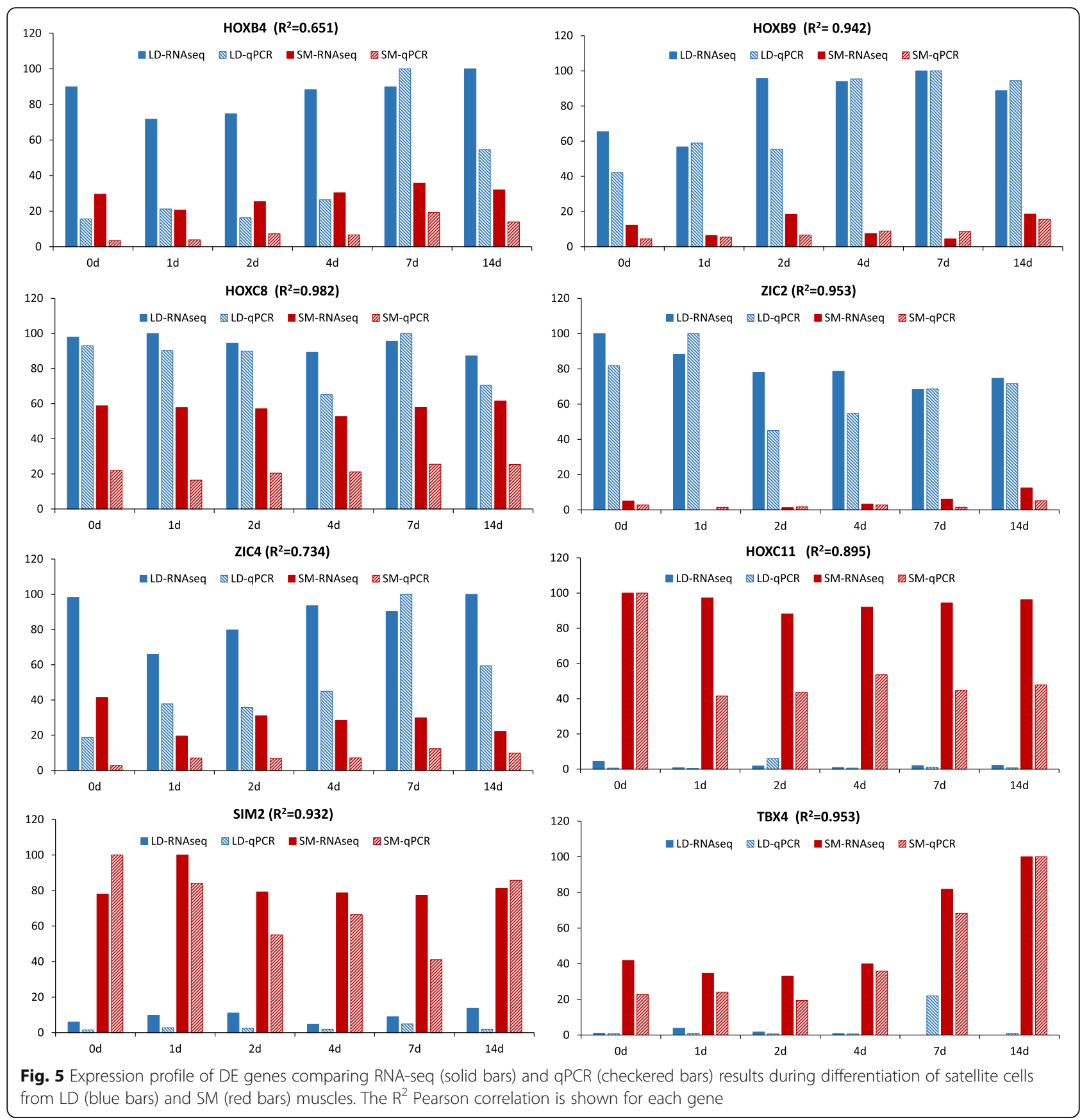

\section{Discussion}

Multiple genes have been identified in model organisms as being important to control the myogenic process. However, this is the first in vitro study to apply a time-series RNA-seq analysis to characterize the transcriptomic differences that occur during the differentiation processes of two distinct bovine MSC depots. Previous studies on bovine MSC have focused on the transcriptional differences in muscle proliferation rates [8], the last stage of differentiation or trans-differentiation of satellite cells [13] and the comparison of muscles [14]. Moreover, most studies have focused on the transcriptional differences between muscles [15], fat [16] or breeds [17] of adult animals.

\section{Transcriptional differences between LD and SM differentiation}

The myogenic process during embryonic development can be approximated by in vitro differentiation of MSC to provide us with a better understanding of the developmental differences between different muscles. We identified consistent differences in the expression of 13 genes (Fig. 5) by comparing Longissimus dorsi (LD) and 
Table $\mathbf{2}$ List of qPCR primers used to validate the expression results from the RNA-seq analysis

\begin{tabular}{ll}
\hline Gene & Sequence $\left(5^{\prime}-3^{\prime}\right)$ \\
\hline RPS9 & Forward - GAGCTGGGTTTGTCGCAAAA \\
(accession no. & Reverse - GGTCGAGGCGGGACTTCT \\
DT860044) & Taqman probe -6FAM-ATGTGACCCCGCGGAG \\
& ACCCTTC-TAMRA
\end{tabular}

Myogenin (accession no. AF091714)

Myo D

(accession no. AB110599)

Myf 5 (accession no. NM_174116)

MYF6 (accession no. NM_181811)

IGF1 (accession no. NM_001077828)

PAX3

(accession no. NM_001206818)

HOXC11 (accession no. NM_001192873)

SIM2 (accession no. XM_015462213)

HOXC8 (accession no. XM_002687232)

HOXB9 (accession no. NM_001191186)

ZIC2 (accession no. NM_001206366)
Forward - AGAAGGTGAATGAAGCCTTCGA

Reverse - GCAGGCGCTCTATGTACTGGAT

Taqman probe - 6FAM-CCCAACCAGAGGCTGC CCAAAGT-TAMRA

Forward - AGGCCTTCGAGACGCTCAA

Reverse - TGGCGTTGCGCAGGAT

Taqman probe - 6FAM-CGCTGCACGTCTAGCA ACCCAAACC-TAMRA

Forward - GGCTTTCGACACGCTCAAG

Reverse - CATTCCTGAGGATCTCCACCTT

Taqman probe - 6FAM-TGCACCACGACCAACC CTAACCAGA-TAMRA

Forward - GGAGGTGGTGGAGAAGTAACTCA

Reverse - GCAGGGAGGGTGGGATCTI GGAGCA-TAMRA

Forward - GGTGAAGATGCCCATCACATC

Reverse - GCTGGTGAAGGCGAGCAA

Taqman probe - 6FAM-TCCTCGCATCTCTTCTA TCTGGCCCTG-TAMRA

Forward - GGACAGCAGCTCTGCCTACTG

Reverse - GAGGCACAAAGCTGTCTGTATAGC

Taqman probe - 6FAM-CTCCCCAGCACCAGG CATGGA-TAMRA

Forward - GCACTTACTACGTGCCTGAGTTCTC

Reverse - TTGGGCCGGGTAGGGATA

Tagman probe - 6FAM-CCCCAGGCCCCCTCTC GTCAG-TAMRA

Forward - CGAAGCTGAGAGCAAACCCTTA

Reverse - CGCACTCCAGTTTGTCCATTT

Taqman probe - 6FAM-CCCGCACAGCAGTAC GGCTCG-TAMRA

Forward - TCGCACCACGTCCAAGACT

Reverse - TCTGCTGGTAGCCCGAGTTG

Tagman probe - 6FAM-CTTCCACCACGGCAC CTCGGG-TAMRA

Forward - GGCAACCCCAGTTCCTCACT

Reverse - TCCCCGGGTGACTITGG

Taqman probe - 6FAM-CCAACCTGCCTGTTCC TTCCCACA-TAMRA

Forward - CAAGCAAGAGCTCATCTGCAAGT

Reverse - TGAAAGTTTTGTTGCAGCTCTTCT

Tagman probe - 6FAM-ATCGACCCCGAGCAG CTGAGTAACC-TAMRA
Tagman probe - 6FAM-TCCGGACGTTCTCCAC
Table 2 List of qPCR primers used to validate the expression results from the RNA-seq analysis (Continued)

\begin{tabular}{|c|c|}
\hline Gene & Sequence $\left(5^{\prime}-3^{\prime}\right)$ \\
\hline \multirow{3}{*}{$\begin{array}{l}\text { ZIC4 } \\
\text { (accession no. } \\
\text { XM_586391) }\end{array}$} & Forward - GCGCCTITGCTCCAAAACT \\
\hline & Reverse - ACGTGCTCCACGGTGACAT \\
\hline & $\begin{array}{l}\text { Taqman probe - 6FAM-TCAGCACCATGCACGA } \\
\text { GCTGGTC-TAMRA }\end{array}$ \\
\hline \multirow{3}{*}{$\begin{array}{l}\text { TBX4 } \\
\text { (accession no. } \\
\text { NM_001192193) }\end{array}$} & Forward - GATGTTCCCCAGCTACAAGGTAA \\
\hline & Reverse - CGATGTCGATCAGCAGGATGT \\
\hline & $\begin{array}{l}\text { Taqman probe - 6FAM-CACGGGCATGAACCCC } \\
\text { AAGACC-TAMRA }\end{array}$ \\
\hline \multirow{3}{*}{$\begin{array}{l}\text { HOXB4 } \\
\text { (accession no. } \\
\text { NM_001078114) }\end{array}$} & Forward - AGTGTITGGCCACGGTAACA \\
\hline & Reverse - CGGCCCCAAGGTGGAA \\
\hline & $\begin{array}{l}\text { Taqman probe - } 6 \text { FAM-CTTCCCCCTCCATGCCC } \\
\text { GTTCA-TAMRA }\end{array}$ \\
\hline
\end{tabular}

Semimembranosus (SM) muscle satellite cells during the differentiation process which suggests that they could be involved in driving muscle compartmentalization. Up regulation of $H O X B 2, H O X B 4, H O X B 9, H O X C 8$, FOXD1, IGFN1, ZIC2 and ZIC4 genes in LD suggest their role in lineage development of MSC into trunk muscles. On the other hand, the higher expression of the genes HOXA11, HOXC11, PITX1, SIM2, and TBX4 in SM could be involved in the development of MSC into limb muscles.

We did not test this in the study, but it is possible that epigenetic regulation during the embryonic development of LD and SM muscles as well as neighboring signals could have imprinted the MSC with specific methylation patterns that resulted in the observed differences in expression patterns during in vitro differentiation. Another study found similarly divergent expression in human abdominal adipose cells where the genes that showed higher expression were generally hypomethylated in the CpG regions and genes with lower expression had CpG regions more associated with hypermethylation when compared to gluteal cells [18]. In the same study, the gene HOXC11 was more expressed in the gluteal cells which lends support to its potential role in the development of limb structures. Epigenetic imprinting is essential for muscle regeneration [19] and to guide the asymmetric division of SC into specific cellular fates [20]. However, methylation studies with LD and SM MSC will be required to understand if there truly are epigenetic differences between these bovine muscle types and what role they play in muscle differentiation.

The expression of HOX seems to be responsible for the correct development of muscles and regulation of muscle-specific genes in mature muscle tissue [21]. In chicken embryos the HOXA11 protein was found in myogenic precursor cells in the early limb bud and its expression gradually reduced as development progressed 
Table 3 Gene Ontology of the differentially expressed genes in LD and SM muscles for days 1, 7 and 14 in relation to day 0. MF: molecular function; CC: cellular components; BP: biological process. Number of DE genes that are up-regulated ( $\uparrow)$ and downregulated $(\downarrow)$

\begin{tabular}{|c|c|c|c|c|c|c|c|}
\hline & & \multicolumn{2}{|l|}{ Day 1} & \multicolumn{2}{|l|}{ Day 7} & \multicolumn{2}{|l|}{ Day 14} \\
\hline & & Term & $D E$ & Term & $D E$ & Term & $D E$ \\
\hline \multirow[t]{14}{*}{$L D$} & MF & Calcium ion binding & $\downarrow 19$ & $\begin{array}{l}\text { Cytoskeletal protein } \\
\text { binding }\end{array}$ & $\uparrow 7 \downarrow 8$ & Receptor activity & $\uparrow 15 \downarrow 2$ \\
\hline & & $\begin{array}{l}\text { Transmembrane } \\
\text { receptor activity }\end{array}$ & $\downarrow 15$ & $\begin{array}{l}\text { Double-stranded } \\
\text { DNA binding }\end{array}$ & $\uparrow 4 \downarrow 6$ & $\begin{array}{l}\text { Cytoskeletal } \\
\text { protein binding }\end{array}$ & $\uparrow 9 \downarrow 8$ \\
\hline & & Hormone activity & $\uparrow 1 \downarrow 7$ & Microtubule binding & $\downarrow 7$ & $\begin{array}{l}\text { Protein kinase } \\
\text { binding }\end{array}$ & $\uparrow 6 \downarrow 5$ \\
\hline & & & & & & $\begin{array}{l}\text { Peptidase inhibitor } \\
\text { activity }\end{array}$ & $\uparrow 4 \downarrow 2$ \\
\hline & CC & Extracellular space & $\uparrow 4 \downarrow 31$ & Cytoskeletal part & $\uparrow 5 \downarrow 20$ & Cytoskeletal part & $\uparrow 7 \downarrow 16$ \\
\hline & & Myofibril & $\downarrow 25$ & Myofibril & $\uparrow 12$ & Myofibril & $\uparrow 13$ \\
\hline & & Sarcomere & $\downarrow 22$ & Microtubule & $\uparrow 12$ & Sarcomere & $\uparrow 12$ \\
\hline & & Actin cytoskeleton & $\downarrow 17$ & Sarcomere & $\uparrow 11$ & $\begin{array}{l}\text { Microtubule } \\
\text { organizing center }\end{array}$ & $\uparrow 1 \downarrow 11$ \\
\hline & & I band & $\downarrow 13$ & I band & $\uparrow 7$ & I band & $\uparrow 6$ \\
\hline & $\mathrm{BP}$ & $\begin{array}{l}\text { Regulation of } \\
\text { multicellular } \\
\text { organismal process }\end{array}$ & $\uparrow 1 \downarrow 37$ & Cell cycle & $\uparrow 1 \downarrow 33$ & Cell cycle & $\uparrow 3 \downarrow 29$ \\
\hline & & $\begin{array}{l}\text { Immune system } \\
\text { process }\end{array}$ & $\uparrow 1 \downarrow 27$ & $\begin{array}{l}\text { Cytoskeleton } \\
\text { organization }\end{array}$ & $\uparrow 5 \downarrow 15$ & Phosphorylation & $\uparrow 13 \downarrow 15$ \\
\hline & & $\begin{array}{l}\text { Muscle structure } \\
\text { development }\end{array}$ & $\downarrow 17$ & $\begin{array}{l}\text { Protein } \\
\text { phosphorylation }\end{array}$ & $\uparrow 6 \downarrow 13$ & Cell proliferation & $\uparrow 9 \downarrow 16$ \\
\hline & & $\begin{array}{l}\text { Actin filament-based } \\
\text { process }\end{array}$ & $\downarrow 14$ & Cell proliferation & $\uparrow 5 \downarrow 13$ & $\begin{array}{l}\text { Muscle structure } \\
\text { development }\end{array}$ & $\uparrow 13 \downarrow 3$ \\
\hline & & $\begin{array}{l}\text { Muscle cell } \\
\text { differentiation }\end{array}$ & $\downarrow 11$ & $\begin{array}{l}\text { Microtubule-based } \\
\text { process }\end{array}$ & $\downarrow 15$ & $\begin{array}{l}\text { Negative regulation } \\
\text { of proteolysis }\end{array}$ & $\uparrow 6 \downarrow 4$ \\
\hline \multirow[t]{14}{*}{$S M$} & MF & & & $\begin{array}{l}\text { Cytoskeletal protein } \\
\text { binding }\end{array}$ & $\uparrow 12 \downarrow 10$ & Receptor binding & $\uparrow 15 \downarrow 16$ \\
\hline & & & & $\begin{array}{l}\text { Peptidase inhibitor } \\
\text { activity }\end{array}$ & $\uparrow 5 \downarrow 4$ & Receptor activity & $\uparrow 27 \downarrow 3$ \\
\hline & & & & Protease binding & $\uparrow 4 \downarrow 2$ & $\begin{array}{l}\text { Cytoskeletal protein } \\
\text { binding }\end{array}$ & $\uparrow 17 \downarrow 12$ \\
\hline & & & & & & $\begin{array}{l}\text { Peptidase inhibitor } \\
\text { activity }\end{array}$ & $\uparrow 7 \downarrow 3$ \\
\hline & CC & Contractile fiber & $\downarrow 10$ & Cytoskeletal part & $\uparrow 23 \downarrow 13$ & Extracellular space & $\uparrow 34 \downarrow 13$ \\
\hline & & Sarcomere & $\downarrow 9$ & Extracellular space & $\uparrow 24 \downarrow 9$ & Cytoskeletal part & $\uparrow 18 \downarrow 24$ \\
\hline & & Myofibril & $\downarrow 9$ & Myofibril & $\uparrow 20$ & Myofibril & $\uparrow 23 \downarrow 1$ \\
\hline & & Actin cytoskeleton & $\downarrow 9$ & Sarcomere & $\uparrow 18$ & Sarcomere & $\uparrow 21 \downarrow 1$ \\
\hline & & I band & $\downarrow 5$ & Microtubule & $\uparrow 1 \downarrow 12$ & I band & $\uparrow 12$ \\
\hline & $\mathrm{BP}$ & $\begin{array}{l}\text { Muscle structure } \\
\text { development }\end{array}$ & $\downarrow 7$ & Cell cycle & $\uparrow 5 \downarrow 34$ & $\begin{array}{l}\text { Immune system } \\
\text { process }\end{array}$ & $\uparrow 36 \downarrow 10$ \\
\hline & & $\begin{array}{l}\text { Regulation of muscle } \\
\text { system process }\end{array}$ & $\downarrow 5$ & $\begin{array}{l}\text { Cytoskeleton } \\
\text { organization }\end{array}$ & $\uparrow 10 \downarrow 16$ & Cell cycle & $\uparrow 6 \downarrow 36$ \\
\hline & & $\begin{array}{l}\text { Striated muscle tissue } \\
\text { development }\end{array}$ & $\downarrow 5$ & $\begin{array}{l}\text { Inflammatory } \\
\text { response }\end{array}$ & $\uparrow 12 \downarrow 3$ & Cell proliferation & $\uparrow 15 \downarrow 23$ \\
\hline & & $\begin{array}{l}\text { Regulation of muscle } \\
\text { contraction }\end{array}$ & $\downarrow 4$ & $\begin{array}{l}\text { Muscle organ } \\
\text { development }\end{array}$ & $\uparrow 12$ & $\begin{array}{l}\text { Cytoskeleton } \\
\text { organization }\end{array}$ & $\uparrow 16 \downarrow 18$ \\
\hline & & & & $\begin{array}{l}\text { G2/M transition } \\
\text { of mitotic cell cycle }\end{array}$ & $\uparrow 1 \downarrow 4$ & $\begin{array}{l}\text { Muscle structure } \\
\text { development }\end{array}$ & $\uparrow 21 \downarrow 5$ \\
\hline
\end{tabular}




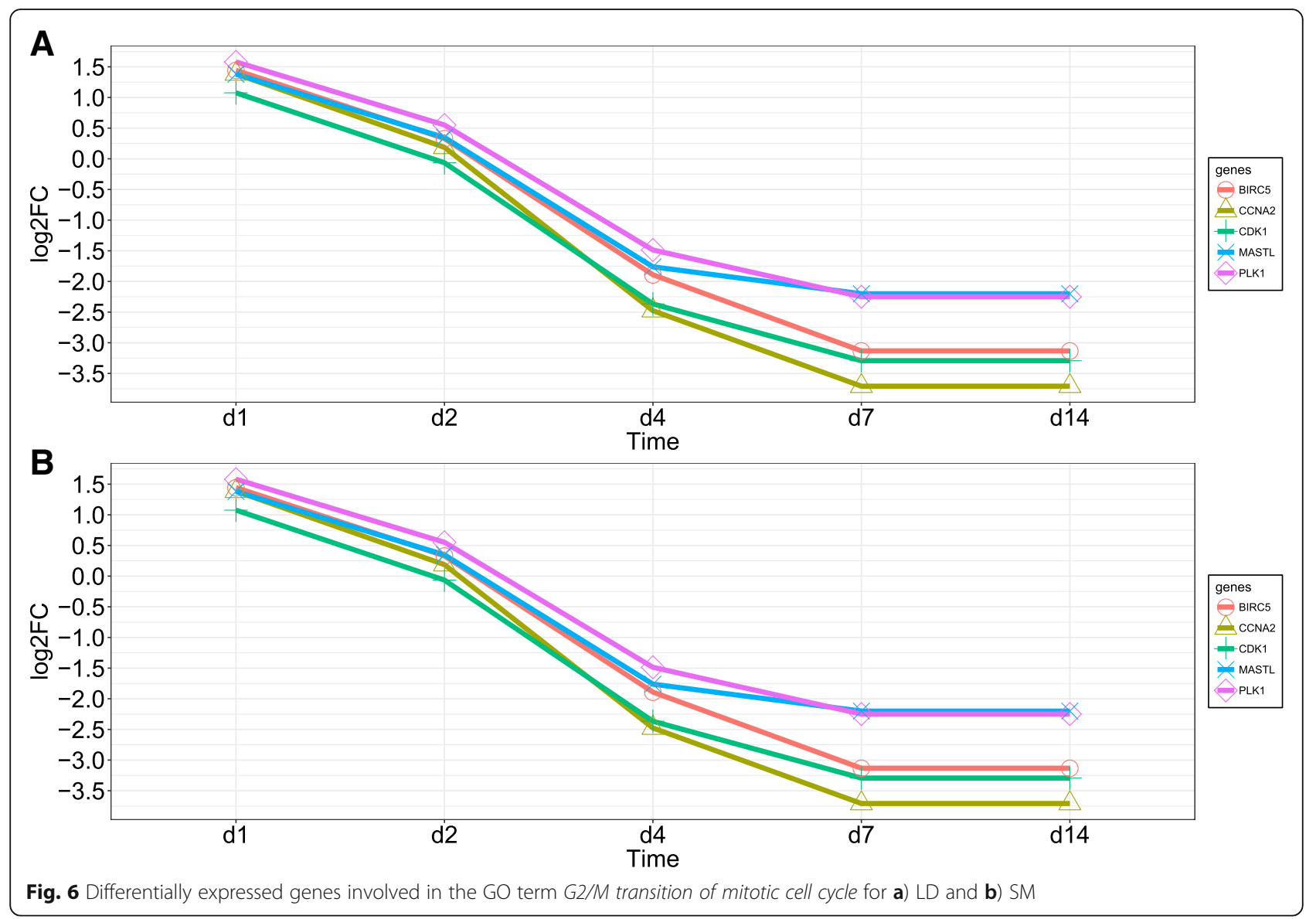

[22]. Also in chicken embryos, this gene is expressed at somite level 33-34 and overlaps with the hindlimb bud [23]. Forced expression of HOXA11 reduces the abundance of $M Y O D$ in the limb of embryo chickens and a similar repression of $M Y O D$ was observed in $\mathrm{C} 2 \mathrm{C} 12$ cells transfected with HOXA11 [24]. The inhibiting action of $H O X A 11$ upstream of $M Y O D$ could explain the higher expression of $M Y O D$ (Fig. 3) observed in LD in relation to SM due to the higher expression of HOXA11 in SM. After day 1 , in both muscles, the expression of MYOD increased after the expression of HOXA11 went down (Additional file 4). These results suggest that HOXA11 can control the speed of differentiation depending of the origin of the muscle (in this case it promoted a delay in the differentiation of SM) which will guide the determination of different muscle types.

Genes from the HOXC cluster (Homeobox C Cluster) were also reported in muscles where myoblast and myotubes showed differential methylation and that these genes present active promoters and enhancer domains that contain MYOD binding sites [25]. HOXC8 and HOXC11 were reported to be involved in the regulation of osteogenesis [26]. Recently it was suggested by [21] that only a subset of muscles may require $\mathrm{HOXC8}$ protein for full activation of muscle-specific gene expression. In chicken and mouse embryos, the expression of HOXC8 lies in the trunk region posterior to the forelimb [23]. In mice embryos (E11.5) the gene HOXC11 was expressed on the rostral side of somite 27, the region involved in the development of hind limb buds [27]. However, the in-situ hybridization in chick embryos showed the location of $\mathrm{HOXC11}$ at somite 36-37 mapping to the seventh sacral vertebrae at the posterior edge of the hindlimb [23].

A study in chicken found that TBX4 seems to be involved in controlling limb identity [28] which supports our conclusion that TBX4 is involved in the regulation of SC differentiation into SM muscle. However, in mice embryos the gene $T B X 4$ seems to regulate muscle and tendon patterning but has not been implicated in their development [29]. SIM2 also upregulated in SM has been shown to be expressed in mice and chicken embryonic limbs and with a higher expression in the ventral limb myoblast [30].

In adult mice, the induced over expression of PITX1 led to significant body weight loss and muscle mass reduction which was primarily caused by muscle atrophy [31]. Using retroviral constructs for PITX1, PITX2 and 
PITX3 in satellite cells from mice, Knopp et al. [32] observed that the increased expression of the paired like homeodomain genes (PITX) suppressed the proliferation of myoblasts and increased the fusion into multinucleated myotubes during differentiation. In mice, Marcil et al. [27] generated double mutants for PITX1 and PITX2 - both mutant embryos lost some hind limb features and had smaller hind limb buds compared to the wild type [27]. In the same study, the expression of TBX4 (assessed by in situ hybridization) decreased around the hind limbs suggesting a role in the specification of hind limbs identity through a cascade that involved TBX4 and PITX1 as an upstream regulatory gene [27].

The deficiency of HOXB4 reduces the capacity of hematopoietic stem cells to proliferate [33]. In myogenic progenitor cells the sub-region that contains $H O X B 4$, HOXB5, HOXB6, HOXB7 and HOXB-AS3 is hypermethylated [25]. During chicken embryo development there are individual cells that express only a subset of the genes depending of the rhombomere of origin. The expression of $\mathrm{HOXB} 4$ was detected in rhombomere 7 while rhombomeres 4 and 5 express HOXB2 [34]. An in-situ hybridization study in chicken and mice associated the expression of HOXB4 with the anterior cervical vertebrae while $H O X B 9$ was mapped to the posterior trunk [23].

Pan et al. [35] used mice to show that the knockdown of ZIC2 resulted in a delay in the activation of MYF5 with a subsequent delay in $M Y O D$, but the expression of $P A X 3$ was not affected by the absence of ZIC2. This is comparable to our results, the expression of ZIC2 was higher in LD which could explain the increase of MYF5 in this muscle at days 0,1 and 2 and subsequently the faster increase of MYOD in LD (Fig. 2). ZIC4 also had a higher expression in LD. During mouse embryogenesis the expression of ZIC4 is in the dorsal midline of the forebrain and in the dorsal spinal neural tube at E12.5, while at the mid-trunk level ZIC4 is restricted to the most dorsal part of the sclerotome and the dorsomedial dermomyotome [36].

FOXD1 is another gene that has been associated with myogenesis control by regulating the expression of $M R F$. During the embryogenesis of flounder, the expression of FOXD1 at the 6 somite stage was found in adaxial cells and progenitor cells of the forebrain, midbrain and kidney [37]. Injection of mRNA FOXD1 reduced the speed of embryo development and the expression of MYOD in the somites, but the adaxial cells were not affected [37]. The negative effect of FOXD1 on MYOD was not clearly observed in our results (Fig. 3, Additional file 4), but there was however a negative correlation between the expression of these genes $(-0.39)$. The correlation is stronger in LD $(-0.65)$ than in SM $(-0.17)$. The higher expression of FOXD1 in LD together with the possible dampening effect on the expression of $M Y O D$ suggests that FOXD1 may also be involved in muscle type differentiation.

\section{Myogenic development of bovine muscle satellite cells}

The bovine MSC presented a pattern of expression in the $M R F$ genes similar to $\mathrm{C} 2 \mathrm{C} 12$ mouse cells during differentiation. As in other studies, MYOD, MYF6 and $M Y O G$ were up-regulated during the differentiation of myoblast into myotubes. This was expected since $M Y O G$ reportedly regulates the fusion of myoblast into multinucleated muscle cells and MYF6 is expressed only in the last stage of the $\mathrm{C} 2 \mathrm{C} 12$ mouse cell during differentiation [38]. A gene expression analysis of the goat muscle rectus abdominis reported that MYOD, MYOG and MYF6 were up-regulated while MYF5 was down-regulated in differentiated myotubes compared with proliferative myotubes [39]. It has also been reported that MYF6 began to be expressed during differentiation [40] and that the protein levels of MYOD, MYF5 and MYOG increased at day 10 of differentiation [12].

We found the same pattern in the transcription levels of MYOG, MYOD and MYF6 for both muscles (but with a significantly higher expression in LD than in SM) indicating that the formation of multinucleated myotubes requires an increase in the expression of $M Y O D$, MYOG and MYF6. Respectively, mRNA abundance levels for each gene started to increase on days 1,2 and 4 and then remained high in the differentiated myotubes on day 14 (Fig. 3). In the case of MYF5, we observed a higher expression in LD on days 0,1 and 2 with a slight reduction after day 2 in LD and day 4 in SM. In $\mathrm{C} 2 \mathrm{C} 12$ myoblasts it was observed that the down-regulation of MYOG levels increased the levels of MYF5 [38] and in MYF5 null mice the differentiation is delayed at an early stage of regeneration [40]. In cattle, the down regulation of MYF5 seems to reduce the proliferation of myoblasts because it maintains satellite cell pools quiescent and reduces the number of activated satellite cells [8]. Together, the expression of these genes could explain the faster developmental differentiation of LD and its higher number of myotubes per area (Fig. 2).

The expression of $P A X 3$ was low but constant, suggesting that some myoblasts were still proliferating as previously reported in mice SC [41] or that it plays a role during the differentiation of bovine muscle. With IGF1, its mRNA abundance increased on days 4, 7 and 14 , which was expected as the IGF1 hormone is one of the most important muscle growth factors secreted by myocytes [9].

\section{Functional analysis}

Overall, the GO enrichment analysis showed that most of the over-represented terms and genes expressed during myoblast differentiation were similar regardless of 
muscle type. We observed more differences in the enriched GO terms during the end of proliferation (day 0 ) compared to myoblast differentiation (days 4 and 7). At the beginning of the experiment, the terms cell cycle, proliferation and G2/M transition of mitotic (Fig. 6) had genes with higher expression, which agrees with the proliferation events that were occurring in the myoblasts. However, the expression of genes involved in these terms started to decrease in the other days due to the shift from cell division to cell differentiation, which is similar to results from previous studies in bovine [5].

From day 2 and onwards the main enriched terms were actin cytoskeleton, myofibril assembly and muscle cell differentiation (Table 3). These changes agreed with the progress of myoblast differentiation and reflected the changes in cellular structure at the cytoskeleton level during myoblast fusion; similar GO terms were already previously reported [12]. Enriched cellular component terms myofibril and contractile fiber are in line with the work of Tripathi et al. [39]. The term inflammatory response was found significant on days 1 and 4 in LD and on days 4, 7 and 14 in SM, consistent with He and Liu [5] who connected it with a muscle regenerative process.

The enrichment of genes (actinin alpha $2-A C T N 2$, calpain 3 - CAPN3, myosin light chain 1 - MYL1, myosin light chain $2-M Y L 2$, complement $\mathrm{C} 1 \mathrm{~s}-\mathrm{C} 1 \mathrm{~S}$ and troponin $\mathrm{C} 1$ - TNNC1) involved in calcium ion binding increased during the differentiation of myoblast into myotubes. During this stage, two main events require an increase in the flow of calcium $(\mathrm{Ca}++): 1)$ the fusion of myoblasts and 2) the development and organization of the contractile apparatus. In previous studies, it was suggested that the concentration of calcium ions influenced the fusion of myoblasts and therefore the number of nuclei in the myotubes of chicken [42]. On one side, Ca++ uptake increases before the fusion of the cytoplasmic vesicles with the cell membrane and acts as an intracellular stimulus [43]. On the other side, muscle contraction requires an increase in calcium-dependent cyclin proteins in order to increase the influx of $\mathrm{Ca}++[44]$.

\section{Conclusion}

The use of satellite cells from newborn Hanwoo calves appears to be a good model to study embryonic myogenesis in muscle. Our findings provide evidence that the differential expression of $H O X B 2, H O X B 4, H O X B 9, H O X C 8$, FOXD1, IGFN1, ZIC2, ZIC4, HOXA11, HOXC11, PITX1, SIM2 and TBX4 genes could be involved in the differentiation of Longissimus dorsi and Semimembranosus muscles. These genes seem to modulate the muscle fate of the satellite cells during myogenesis through a differential expression profile that also controls the expression of some myogenic regulatory factors (MYOD and MYF5). It is possible that the different profiles observed in the cell cultures are due to the origin of the satellite cells that where epigenetically imprinted during the embryonic development of Longissimus dorsi and Semimembranosus. However, epigenetic studies with LD and SM MSC will be required to understand if there truly are epigenetic differences between these bovine muscle types and what role they play in muscle differentiation.

\section{Methods}

\section{Isolation of bovine satellite cells}

Satellite cells were isolated from Longissimus dorsi (LD) and Semimembranosus (SM) muscle samples of three unrelated Korean Hanwoo newborn calves to investigate gene expression changes during differentiation of myoblasts fusing into multinucleate myotubes. Tissues were collected from calves that died spontaneously during delivery from Hanwoo mothers belonging to the Hanwoo Research Institute's cattle herd (NIAS, Korea). The study was approved under the animal care and use protocols 2015-112 and 2018-319 by the Institutional Animal Care and Use Committee of the National Institute of Animal Science, Korea.

Satellite cells were then excised from the LD and SM tissues as previously described in $[45,46]$. Briefly, the muscle samples were cut into $600-700 \mathrm{~g}$ pieces and transferred into a $1000 \mathrm{ml}$ beaker with phosphate buffered saline (PBS). The samples were then transferred to a sterile area in a laboratory and the connective tissue was removed in the tissue culture hood. The muscles were then chopped up with sterile scissors and placed in satellite cell isolation buffer for incubation. Samples $(250 \mathrm{~g})$ were incubated with $300 \mathrm{ml}$ of $0.1 \%$ pronase in Earl's Balanced Salt Solution (EBSS) for $1 \mathrm{~h}$ at $37^{\circ} \mathrm{C}$ with frequent mixing. Following incubation, the mixture was centrifuged at $1500 \mathrm{x} \mathrm{g}$ for $4 \mathrm{~min}$ and the supernatant was discarded. The pellet was suspended in phosphate-

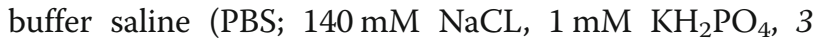
$\left.m M \mathrm{KCl}, 8 \mathrm{mM} \mathrm{Na} \mathrm{HPO}_{4}\right)$ and the suspension was centrifuged at $500 \mathrm{x} g$ for $10 \mathrm{~min}$. The resulting supernatant was centrifuged at $1500 \mathrm{x} \mathrm{g}$ for $10 \mathrm{~min}$ to pellet the mononucleated cells. The PBS was washed, and the differential centrifugation process was repeated another two times. Afterwards, the resultant mononucleated cell preparation was suspended in cold $\left(4^{\circ} \mathrm{C}\right)$ Dulbecco's Modified Eagle Medium (DMEM) that contains 10\% fetal bovine serum (FBS) and 10\% (vol/vol) dimethylsulfoxide (DMSO) and frozen for subsequent studies.

\section{Satellite cell culture}

Hanwoo satellite cells from both LD and SM muscles were separately plated on $225-\mathrm{cm}^{2}$ culture plates percolated with reduced growth factor basement membrane Matrigel, diluted 1:10 (vol/vol) with DMEM containing 10\% FBS and incubated at $37^{\circ} \mathrm{C}, 5 \% \mathrm{CO}_{2}$ in a water-saturated 
environment. Plating density was $2 \times 10^{4}$ cells $/ \mathrm{ml}$ so that all cultures were approximately 60 to $70 \%$ confluent after the incubation period. This ensured that the cell proliferation rate was not affected by contact inhibition. Cultures were fed at $48 \mathrm{~h}$ with DMEM containing 10\% FBS.

\section{Differentiation treatment and cell sample collection}

Cultures that reached confluence (considered as day 0 ) were stimulated to differentiate with an induction medium that consisted of DMEM with $3 \%$ horse serum for 14 days. Plates were triplicated for each sample for the RNA-seq and morphological analyses. Samples from the LD and SM satellite cell cultures from each of the three biological replicates were scrapped from the dishes at six time points (days 0, 1, 2, 4, 7 and 14) and transferred to NuncTM Cryobank Vial System tubes with 1 ml capacity (Thermo Fisher Scientific, Carlsbad, CA, USA). Samples were carefully frozen with liquid nitrogen and then stored at $-80^{\circ} \mathrm{C}$ until RNA extraction.

\section{Histological procedures}

We performed Hematoxylin staining to determine the stages of differentiation and the differentiation index (at days 3,4 and 7 ) of the culture plates for each muscle. The differentiation index is defined as the area, in percentage, occupied by the myotubes in the cultures. This index was calculated by calculating the area occupied by myotubes in at least five photographs taken from random fields of each plate. Photographs were taken using a Nikon NIS-elements (version 4.0; F-package) and Nikon Mi2 microscope with 20X phase-contrast objective. Differences in the index between LD and SM muscles at each time point were tested with an analysis of variance for a model fitting time (day), tissue and the interaction between time and tissue. $P$-values $<0.05$ were considered significantly different.

\section{Immunohistochemical procedures}

The differentiation of LD and SM muscle satellite cells (MSC) was evaluated by immunohistochemistry using a glucose transporter 4. (GLUT4; Abcam) antibody at days 0, 1 and 4 and a Myosin Light Chain (MLC; Abcam) antibody at day 7. Cultured cells were permeabilized using Triton 100 with PBS. Sections were blocked with a $10 \%$ goat serum in PBS, after which they were incubated with the GLUT4 and MLC antibody $(20 \mu \mathrm{l} / \mathrm{mL}$, Abcam) for $1 \mathrm{~h}$. After washing with PBS for $5 \mathrm{~min}$, cultures were treated with the second antibody for another hour at room temperature and then, after PBS washing, stained with Hoechst $(1.5 \mu \mathrm{g} / \mathrm{ml})$ for $1 \mathrm{~h}$. A negative control experiment was also carried out by omitting the antibody. Photographs were taken using a Nikon NIS-elements (version 4.0; F-package) and Nikon Mi2 microscope with 20X phase-contrast objective and a red filter. Nikon
TRITC was used for wavelength detection from excitation 540 to barrier 605 . The wavelength of secondary antibody (Alexa 568; Abcam 175,696) was between 578 $\mathrm{nm}$ excitation and $603 \mathrm{~nm}$ emission.

\section{RNA extraction and sequencing}

RNA from the satellite cell cultures of the three Hanwoo calves was extracted from the LD and SM muscles for the six time points (days $0,1,2,4,7$ and 14). Total RNA was isolated with TRIzol following the manufacturer's protocol (Invitrogen, Carlsbad, CA, USA). RNA quality and quantity were assessed using an automated capillary gel electrophoresis on a Bioanalyzer 2100 with RNA 6000 Nano Labchips according to the manufacturer's instructions (Agilent Technologies Ireland, Dublin, Ireland). High-quality RNA (RNA integrity number $>7.2$ ) was processed using the Illumina TruSeq RNA Sample Preparation Kit (Illumina, San Diego, CA, USA) following the manufacturer's procedures. The final individual RNA-Seq libraries were constructed using the Illumina Hiseq2000 platform, which created $100 \mathrm{bp} /$ paired-end $(\mathrm{PE})$ sequence reads.

\section{RNA-seq analysis}

Quality of the RNA sequence data was evaluated with FastQC v0.11.3 [47]. Low quality bases and adaptor sequences were removed with Trimmomatic v0.33 [48]. Reads were mapped to the reference genome (Bos taurus Ensembl UMD3.1) using Bowtie2 v2.2.6 [49]. Reads that mapped to multiple sites, single reads and unmapped reads were excluded from the analysis. Downstream analyses were performed with the statistical programming language R [50] and various R packages. GenomicFeatures v1.22.13 [51] and GenomicAlignments v1.6.3 [51] were used to annotate and count the reads. Principal Components Analysis (PCA) was used to evaluate the clustering of the samples (time points and muscle types). edgeR 3.12.0 [52] was used for the analysis of differentially expressed (DE) genes by fitting a generalized linear model with a negative binomial distribution to model the data effects for time and tissue. RNA composition was normalized with the scaling factors from the trimmed means of the M-values using edgeR. Gene expression differences between muscles (LD vs SM) at each timepoint were evaluated as well as the changes in expression over time for each muscle in relation to day 0 . Genes were considered as differentially expressed for a log fold change $\geq 2$ (or $\leq 2$, depending on the order of the contrast) [52] and a false discovery rate (FDR) adjusted $p$-value $<0.05$. The differentially expressed genes found in the study were tested with ClusterProfiler v2.5.5 [53] for Gene Ontology (GO) and Pathway enrichment analyses. This $\mathrm{R}$ package uses data from the Gene Ontology and the Kyoto Encyclopedia of Genes and Genome (KEGG) databases to test for over-representation of $\mathrm{DE}$ genes in ontologies and pathways. For 
both analyses we considered terms and pathways as significant for a cutoff $\mathrm{q}$-value $<0.05$ to reduce false discovery rates due to multiple testing. The $\mathrm{DE}$ genes in the overrepresented terms had their expression across time (fold change ratio relative to day 0) graphed to evaluate the dynamics of expression changes from day 0 to 14 . We also used VennDiagram v1.6.18 [54] to visualize overlap of differentially expressed genes across time points for each muscle. The background set of genes for both enrichment analyses consisted of the bovine genes expressed in this study after quality control.

\section{qPCR validation of differentially expressed genes}

From the list of differentially expressed genes, eight were randomly selected for validation using quantitative PCR (qPCR). Expression of the MRF genes was also measured with qPCR due to their known role in myogenic processes. Total RNA was isolated from LD and SM muscle satellite cell cultures at six time points (days $0,1,2,4,7$ and 14) from three independent biological replicates. Reverse transcription to cDNA was performed using the commercial kit SuperScript III First-Strand Synthesis Supermix (Thermo Fisher Scientific, Carlsbad, CA, USA) following the manufacturer's instructions. The primer sequences are listed in Table 2.

The measurement of the relative quantity of the cDNA of interest was performed using TAMRA PCR Master Mix (Applied Biosystems) with the appropriate forward and reverse primers and $1 \mu \mathrm{L}$ of the cDNA mixture. We used the Sequence Detection System (Applied Biosystems) with the thermal cycling parameters recommended by the manufacturer ( 40 cycles of $15 \mathrm{~s}$ at $95^{\circ} \mathrm{C}$ and $1 \mathrm{~min}$ at $60^{\circ} \mathrm{C}$ ). Relative expression was quantified with the $2^{-\Delta \Delta C t}$ method [55]. All sample values were normalized against the ribosomal protein S9 (RPS9) gene and expressed in arbitrary units. Titration of MRF mRNA primers against increasing amounts of cDNA gave linear responses with slopes between -2.8 and -3.0 . To reduce the effect of assay-to-assay variation in the PCR assay, all values were calculated relative to a calibration standard run on every real-time PCR assay.

We used an ANOVA analysis to test the effects of tissue, time and the tissue by time interaction. Data were analyzed as a 2 (tissue) $\times 6$ (time) factorial arrangement of treatments in a randomized complete block design with the PROC MIXED procedure (SAS Inst. Inc., Cary, NC). Main effects and interaction means were separated $(P<0.05)$ with the LSMEANS procedure of SAS. $P$-values came from the ANOVA analysis of the linear model:

$$
\mathrm{y} \sim \mu+\text { treatment }+ \text { tissue }+ \text { treatment } \times \text { tissue }+\mathrm{e}
$$

where treatment indicates time series for days $0,1,2,4$, 7 and 14 (6 levels) and tissue is LD and SM (2 levels).

\section{Additional files}

Additional file 1: Table S1. Summary of preprocessing of RNA-seq reads and mapping steps for each sample. (DOCX $17 \mathrm{~kb}$ )

Additional file 2: Figure S1. Principal component analysis of the expression profiles for each time point and muscle type. (PDF $60 \mathrm{~kb}$ )

Additional file 3: Table S2. List of differentially expressed genes from the contrast LD vs SM and contrasts at each time point. (XLSX 380 kb)

Additional file 4: Figure S2. Expression profile of LD and SM in $\log _{2}$ (cpm). (PDF $165 \mathrm{~kb}$ )

Additional file 5: Table S3. Gene Ontology results for each of the time contrasts. (XLSX $73 \mathrm{~kb}$ )

Additional file 6: Table S4. Pathway enrichment analysis of contrasts over time for LD and SM. (XLSX $26 \mathrm{~kb})$

\section{Abbreviations}

BP: Biological process; CC: Cellular components; CPM: Copies per Million; DE: Differentially expressed; LD: Longissimus dorsi; MF: Molecular function; MRF: Myogenic regulatory factors; MSC: Muscle satellite cells;

SM: Semimembranosus

\section{Acknowledgements}

Not applicable.

\section{Funding}

This work was carried out with the support of the Cooperative Research Program for Agriculture Science \& Technology Development (Project No. PJ01091002 and PJ01361501) Rural Development Administration, Republic of Korea. The funding body had no role in the design of the study, collection, analysis, and interpretation of data, or in writing the manuscript.

Availability of data and materials Summary data for this study are included in this published article as supplementary material. Raw RNA-seq data are available from the corresponding authors on reasonable request.

\section{Authors' contributions}

KYC, SHL and CG designed the study. KYC and SHL collected the samples and performed the RNA sequencing and phenotyping. SHS, KYC and CG analyzed the data. SHS and CG wrote the manuscript. KYC and SHL revised the manuscript. All authors read and approved the final manuscript.

\section{Ethics approval}

Tissue sampling was done in accordance with the animal care and use protocol of the IACUC of the National Institute of Animal Science (Approval numbers: 2015-112 and 2018-319).

Consent for publication

Not applicable.

\section{Competing interests}

The authors declare that they have no competing interest.

\section{Publisher's Note}

Springer Nature remains neutral with regard to jurisdictional claims in published maps and institutional affiliations.

\section{Author details}

${ }^{1}$ School of Environmental and Rural Science, University of New England, Armidale, NSW, Australia. ' Hanwoo Research Institute, National Institute of Animal Science, RDA, Pyeongchang, South Korea. ${ }^{3}$ Division of Animal and Dairy Science, Chungnam National University, Deajeon, South Korea.

${ }^{4}$ Department of Animal Science, Michigan State University, 474 S Shaw Lane, East Lansing, MI 48824, USA. 
Received: 3 July 2018 Accepted: 13 February 2019

\section{Published online: 26 February 2019}

\section{References}

1. Cho S, Park B, Kim J, Hwang I, Kim J, Lee J. Fatty acid profiles and sensory properties of longissimus dorsi, triceps brachii, and semimembranosus muscles from Korean Hanwoo and Australian Angus beef. Asian Australas J Anim Sci. 2005;18(12):1786.

2. Hocquette J, Renand G, Levéziel H, Picard B, Cassar-Malek I. The potential benefits of genetics and genomics to improve beef quality-a review. Anim Sci Paper Rep. 2006;24(3):173-86.

3. Jung $E$, Hwang $Y$, Joo $S$. The relationship between chemical compositions, meat quality, and palatability of the 10 primal cuts from Hanwoo steer. Korean J Food Sci Anim Resour. 2016;36(2):145.

4. Guo B, Greenwood PL, Cafe LM, Zhou G, Zhang W, Dalrymple BP. Transcriptome analysis of cattle muscle identifies potential markers for skeletal muscle growth rate and major cell types. BMC Genomics. 2015;16(1):177.

5. He H, Liu X. Characterization of transcriptional complexity during longissimus muscle development in bovines using high-throughput sequencing. PLoS One. 2013;8(6):e64356.

6. Chaze T, Meunier B, Chambon C, Jurie C, Picard B. In vivo proteome dynamics during early bovine myogenesis. Proteomics. 2008;8(20):4236-48

7. Lee EJ, Bajracharya P, Lee D-M, Kang SW, Lee YS, Lee H-J, Hong SK, Chang J, Kim JW, Schnabel RD. Gene expression profiles during differentiation and transdifferentiation of bovine myogenic satellite cells. Genes Genom. 2012; 34(2):133-48.

8. Coles CA, Wadeson J, Leyton CP, Siddell JP, Greenwood PL, White JD, McDonagh MB. Proliferation rates of bovine primary muscle cells relate to liveweight and carcase weight in cattle. PLoS One. 2015;10(4):e0124468.

9. Braun T, Gautel M. Transcriptional mechanisms regulating skeletal muscle differentiation, growth and homeostasis. Nat Rev Mol Cell Biol. 2011;12(6):349.

10. Eng D, Ma H-Y, Gross MK, Kioussi C. Gene networks during skeletal myogenesis. ISRN Dev Biol. 2013;2013. Article ID 348704. https://doi.org/10. $1155 / 2013 / 348704$

11. Lee EJ, Malik A, Pokharel S, Ahmad S, Mir BA, Cho KH, Kim J, Kong JC, Lee D, Chung KY. Identification of genes differentially expressed in myogenin knock-down bovine muscle satellite cells during differentiation through RNA sequencing analysis. PLoS One. 2014;9(3):e92447.

12. Rajesh RV, Jang E, Choi I, Heo K, Yoon D, Kim T, Lee H. Proteomic analysis of bovine muscle satellite cells during myogenic differentiation. Asian Australas J Anim Sci. 2011;24(9):1288-302.

13. Lee EJ, Kamli MR, Pokharel S, Malik A, Tareq K, Bhat AR, Park H, Lee YS, Kim S, Yang B. Expressed sequence tags for bovine muscle satellite cells, myotube formed-cells and adipocyte-like cells. PLoS One. 2013:8(11):e79780.

14. Lee EJ, Lee HJ, Kamli MR, Pokharel S, Bhat AR, Lee Y, Choi B, Chun T, Kang SW, Lee YS. Depot-specific gene expression profiles during differentiation and transdifferentiation of bovine muscle satellite cells, and differentiation of preadipocytes. Genomics. 2012;100(3):195-202.

15. Moreno-Sánchez N, Rueda J, Carabaño MJ, Reverter A, McWilliam S, González C, Díaz C. Skeletal muscle specific genes networks in cattle. Funct Integr Genomics. 2010;10(4):609-18.

16. Lee HJ, Park HS, Kim W, Yoon D, Seo S. Comparison of metabolic network between muscle and intramuscular adipose tissues in Hanwoo beef cattle using a systems biology approach. Int J Genomics. 2014;2014

17. Giusti J, Castan E, Dal Pai M, Arrigoni MDB, Baldin SR, De Oliveira HN. Expression of genes related to quality of longissimus dorsi muscle meat in Nellore (Bos indicus) and Canchim (5/8 Bos taurus $\times 3 / 8$ Bos indicus) cattle. Meat Sci. 2013;94(2):247-52.

18. Gehrke S, Brueckner B, Schepky A, Klein J, Iwen A, Bosch TC, Wenck H, Winnefeld M, Hagemann S. Epigenetic regulation of depot-specific gene expression in adipose tissue. PLoS One. 2013;8(12):e82516.

19. Dilworth $\mathrm{F}$, Blais $\mathrm{A}$. Epigenetic regulation of satellite cell activation during muscle regeneration. Stem Cell Res Ther. 2011;2(2):18.

20. Yin H, Price F, Rudnicki MA. Satellite cells and the muscle stem cell niche. Physiol Rev. 2013;93(1):23-67

21. Houghton $L$, Rosenthal N. Regulation of a muscle-specific transgene by persistent expression of hox genes in postnatal murine limb muscle. Dev Dyn. 1999:216(4-5):385-97.

22. Hashimoto K, Yokouchi Y, Yamamoto M, Kuroiwa A. Distinct signaling molecules control Hoxa-11 and Hoxa-13 expression in the muscle precursor and mesenchyme of the chick limb bud. Development. 1999;126(12):2771-83.
23. Burke AC, Nelson CE, Morgan BA, Tabin C. Hox genes and the evolution of vertebrate axial morphology. Development. 1995;121(2):333-46.

24. Yamamoto M, Kuroiwa A. Hoxa-11 and Hoxa-13 are involved in repression of MyoD during limb muscle development. Develop Growth Differ. 2003; 45(5-6):485-98.

25. Tsumagari K, Baribault C, Terragni J, Chandra S, Renshaw C, Sun Z, Song L, Crawford GE, Pradhan S, Lacey M. DNA methylation and differentiation: HOX genes in muscle cells. Epigenetics Chromatin. 2013;6(1):25.

26. Chae SW, Jee BK, Lee JY, Han CW, Jeon Y, Lim Y, Lee K, Rha HK, Chae G. HOX gene analysis in the osteogenic differentiation of human mesenchymal stem cells. Genet Mol Biol. 2008;31(4):815-23.

27. Marcil A, Dumontier É, Chamberland M, Camper SA, Drouin J. Pitx1 and Pitx2 are required for development of hindlimb buds. Development. 2003; 130(1):45-55.

28. Rodriguez-Esteban C, Tsukui T, Yonei S, Magallon J, Tamura K, Belmonte JCl. The T-box genes Tbx4 and Tbx5 regulate limb outgrowth and identity. Nature. 1999:398(6730):814

29. Hasson P, DeLaurier A, Bennett M, Grigorieva E, Naiche L, Papaioannou VE, Mohun TJ, Logan MP. Tbx4 and tbx5 acting in connective tissue are required for limb muscle and tendon patterning. Dev Cell. 2010;18(1):148-56.

30. Coumailleau P, Duprez D. Sim 1 and Sim2 expression during chick and mouse limb development. Int J Dev Biol. 2003;53(1):149-57.

31. Pandey SN, Cabotage J, Shi R, Dixit M, Sutherland M, Liu J, Muger S, Harper SQ, Nagaraju K, Chen Y. Conditional over-expression of PITX1 causes skeletal muscle dystrophy in mice. Biol Open. 2012;1(7):629-39.

32. Knopp P, Figeac N, Fortier M, Moyle L, Zammit PS. Pitx genes are redeployed in adult myogenesis where they can act to promote myogenic differentiation in muscle satellite cells. Dev Biol. 2013;377(1):293-304.

33. Björnsson JM, Larsson N, Brun AC, Magnusson M, Andersson E, Lundström P, Larsson J, Repetowska E, Ehinger M, Humphries RK. Reduced proliferative capacity of hematopoietic stem cells deficient in Hoxb3 and Hoxb4. Mol Cell Biol. 2003;23(11):3872-83.

34. Kato K, O'dowd DK, Fraser SE, Smith MA. Heterogeneous expression of multiple putative patterning genes by single cells from the chick hindbrain. Dev Biol. 1997;191(2):259-69.

35. Pan H, Gustafsson MK, Aruga J, Tiedken JJ, Chen JC, Emerson CP. A role for Zic1 and Zic2 in Myf5 regulation and somite myogenesis. Dev Biol. 2011; 351(1):120-7.

36. Gaston-Massuet C, Henderson DJ, Greene ND, Copp AJ. Zic4, a zinc-finger transcription factor, is expressed in the developing mouse nervous system. Dev Dyn. 2005;233(3):1110-5.

37. Zhang $Y$, Tan X, Sun W, Zhang P. Flounder (Paralichthys olivaceus) FoxD1 and its regulation on the expression of myogenic regulatory factor, MyoD Biologia. 2012;67(5):992-1000.

38. Mastroyiannopoulos NP, Nicolaou P, Anayasa M, Uney JB, Phylactou LA. Down-regulation of myogenin can reverse terminal muscle cell differentiation. PLoS One. 2012:7(1):e29896.

39. Tripathi AK, Patel AK, Shah RK, Patel AB, Shah TM, Bhatt VD, Joshi CG. Transcriptomic dissection of myogenic differentiation signature in caprine by RNA-Seq. Mech Dev. 2014;132:79-92.

40. Gayraud-Morel B, Chrétien F, Flamant P, Gomès D, Zammit PS, Tajbakhsh S. A role for the myogenic determination gene Myf5 in adult regenerative myogenesis. Dev Biol. 2007;312(1):13-28.

41. Lagha M, Sato T, Regnault B, Cumano A, Zuniga A, Licht J, Relaix F, Buckingham M. Transcriptome analyses based on genetic screens for Pax3 myogenic targets in the mouse embryo. BMC Genomics. 2010;11(1):696.

42. Ozawa $\mathrm{E}$. The role of calcium ion in avian myogenesis in vitro. Biol Bull. 1972;143(2):431-9.

43. Przybylski RJ, MacBride RG, Kirby AC. Calcium regulation of skeletal myogenesis. I. Cell content critical to myotube formation. InVitro Cell Dev Biol. 1989;25(9):830-8.

44. Kislinger $T$, Gramolini AO, Pan Y, Rahman K, MacLennan DH, Emili A. Proteome dynamics during C2C12 myoblast differentiation. Mol Cell Proteomics. 2005:4(7):887-901.

45. Frey RS, Johnson BJ, Hathaway MR, White ME, Dayton WR. Growth factor responsiveness of primary satellite cell cultures from steers implanted with trenbolone acetate and estradiol-17ß. Basic Appl Myol. 1995;5:71-9.

46. Johnson B, Halstead N, White M, Hathaway M, DiCostanzo A, Dayton W. Activation state of muscle satellite cells isolated from steers implanted with a combined trenbolone acetate and estradiol implant. J Anim Sci. 1998; 76(11):2779-86. 
47. Andrews S. FastQC: a quality control tool for high throughput sequence data; 2010.

48. Bolger AM, Lohse M, Usadel B. Trimmomatic: a flexible trimmer for Illumina sequence data. Bioinformatics. 2014;30(15):2114-20.

49. Langmead B, Salzberg SL. Fast gapped-read alignment with bowtie 2. Nat Methods. 2012;9(4):357-9.

50. R core Team. R: a language and environment for statistical computing. Vienna: R Foundation for Statistical Computing; 2017.

51. Lawrence M, Huber W, Pages H, Aboyoun P, Carlson M, Gentleman R, Morgan MT, Carey VJ. Software for computing and annotating genomic ranges. PLoS Comput Biol. 2013;9(8):e1003118.

52. Robinson MD, McCarthy DJ, Smyth GK. edgeR: a Bioconductor package for differential expression analysis of digital gene expression data. Bioinformatics. 2010;26(1):139-40.

53. Yu G, Wang LG, Han Y, He QY. clusterProfiler: an R package for comparing biological themes among gene clusters. Omics. 2012;16(5):284-7.

54. Chen $\mathrm{H}$, Boutros PC. VennDiagram: a package for the generation of highlycustomizable Venn and Euler diagrams in R. BMC Bioinforma. 2011;12(1):35.

55. Livak K, Schmittgen TD. Analysis of relative gene expression data using realtime quantitative PCR and the $2-\Delta \Delta C T$ method. Methods. 2001;25(4):402-8.

Ready to submit your research? Choose BMC and benefit from:

- fast, convenient online submission

- thorough peer review by experienced researchers in your field

- rapid publication on acceptance

- support for research data, including large and complex data types

- gold Open Access which fosters wider collaboration and increased citations

- maximum visibility for your research: over $100 \mathrm{M}$ website views per year

At $\mathrm{BMC}$, research is always in progress.

Learn more biomedcentral.com/submissions 